\title{
Use of Acridine Orange to Visually Improve the Loop-mediated Isothermal Amplification for Detection of Infectious Spleen and Kidney Necrosis Virus
}

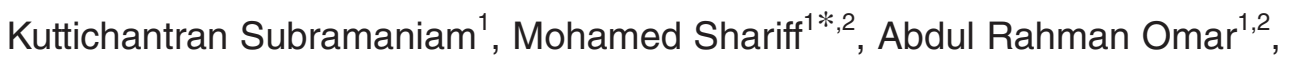 \\ Mohd Hair-Bejo ${ }^{1}$ and Bee Lee Ong ${ }^{1}$ \\ ${ }^{1}$ Faculty of Veterinary Medicine, Universiti Putra Malaysia, 43400, Selangor, Malaysia \\ ${ }^{2}$ Institute of Bioscience, Universiti Putra Malaysia, 43400, Selangor, Malaysia
}

(Received July 20, 2014)

\begin{abstract}
The advancement in nucleic acid amplification has improved the diagnostic methods for many diseases. In the current study, an improved technique for the detection of infectious spleen and kidney necrosis virus (ISKNV) based on loop-mediated isothermal amplification (LAMP) is described. The addition of acridine orange at the end of the reaction causes distinct color change which can be recognized by the naked eye. In addition, a new set of primers was designed based on the ISKNV major capsid protein (MCP) gene sequences. The primers are highly specific for ISKNV and there was no cross amplification with red sea bream iridovirus (RSIV), white spot syndrome virus (WSSV), Aeromonas hydrophila or Vibrio parahaemolyticus. The detection limit of LAMP assay was $1.4 \times 10^{4}$ copies of the virus DNA and the optimum temperature and time for assay was $65^{\circ} \mathrm{C}$ and $60 \mathrm{~min}$ respectively, and this protocol could successfully detect the virus from asymptomatically infected fish. This improved LAMP assay is a simple and inexpensive diagnostic tool for the detection of ISKNV without the need of specialized equipment.
\end{abstract}

Key words: infectious spleen and kidney necrosis virus, Megalocytivirus, major capsid protein gene, loop-mediated isothermal amplification, acridine orange, LAMP

Viruses, bacteria, fungi and metazoan parasites have caused various infectious diseases in aquaculture industry (Meyer, 1991; Whittington and Chong, 2007). Infectious spleen and kidney necrosis virus (ISKNV) is a piscine virus which has been detected in different fish species such as mandarin fish, Siniperca chuatsi; African lampeye, Aplocheilichthys normani; dwarf gourami, Colisa lalia; murray cod, Maccullochella peelii peelii; zebrafish, Danio rerio; ramirezi cichlids, Mikrogeophagus ramirezi; common platy, Xiphophorus maculates; swordtail, Xiphophorus helleri; and pearl gourami, Trichogaster leerii (Subramaniam et al., 2012, 2014). The ISKNV which belongs to genus Megalocytivirus has a double stranded DNA as their genome and distributed in both tropical (Thailand, Singapore, Taiwan) and temperate (Japan, Korea) regions (Song et al., 2008).

Diagnostic methods such as histopathology and transmission electron microscopy (TEM) have been utilized for the detection of ISKNV (Armstrong and Ferguson, 1989; Paperna et al., 2001; Sudthongkong et

\footnotetext{
* Corresponding author

E-mail: pshariff@gmail.com
}

al., 2002). However, these methods have limited specificity and cannot be used to detect low numbers of pathogens (Ambrosia and De Wall, 1990). In addition, visual inspection for clinical signs is not suitable to monitor the viral disease as ISKNV is able to establish either symptomatic or asymptomatic infection in fish (Subramaniam et al., 2014). Hence, a highly specific and simple method is needed to detect the presence of ISKNV.

Advances in nucleic acid amplification methods have been substantial in recent years and have improved the laboratory diagnosis for many diseases. One of the most common and widely used diagnostic methods is polymerase chain reaction (PCR) (Tomlinson et al., 2007). Several studies have reported diagnostic protocols on the detection of ISKNV by PCR (Go et al., 2006; Wang et al., 2007; Fu et al., 2010). Most recently, quantitative polymerase chain reaction (qPCR) method was developed by Rimmer et al. (2012) to detect dwarf gourami iridovirus (DGIV) which was considered as a variant of ISKNV. However, the above mentioned protocols cannot be carried out in resource limited laboratories and field due to the requirement of thermal cycler. 
In 2000, Notomi and his colleagues developed a novel method for nucleic acid amplification and referred it as loop-mediated isothermal amplification (LAMP) (Notomi et al., 2000). Unlike PCR, the target DNA is amplified by auto-cycling strand displacement using Bst DNA polymerase. In addition, there are a set of four specific primers which recognize a total of six distinct regions on the target sequence. LAMP method has the advantages of speed and able to synthesize large amount of DNA at isothermal condition (Mori et al., 2001; Ding et al., 2010). Moreover, successful amplification of target DNA can be detected by observing the presence of white precipitate (magnesium pyrophosphate) without the use of agarose gel electrophoresis (Mori et al., 2001; Pillai et al., 2006). More details on the principles underlying LAMP reaction are available at Notomi et al. (2000) and Tomita et al. (2008). The LAMP assay has been successfully used for the detection of bacteria, viruses, fungi and parasites in both animal and plants (Savan et al., 2005). In addition, it has been also applied for the detection of bacterial and viral pathogens of fish and shellfish (Biswas and Sakai, 2014).

Subsequently, Ding et al. (2010) have developed ISKNV LAMP assay combined with a lateral flow dipstick (LFD). Despite this development, LFD strips and synthesis of hybridization probe increase the cost of the assay. In addition, the post reaction procedure involving LFD strips may increase the risk of contamination. According to Tomita et al. (2008), even a small amount of contamination of amplified product may lead to inaccurate results. As an alternate to lateral flow dipstick, several LAMP-based methods have utilized SYBR Green and Calcein to visualize the amplified product. However, cost is a big constraint in using aforementioned dyes (Goto et al., 2009). Hence a cheap and easily visible dye is needed to visualize the amplified LAMP product.

In this study, addition of acridine orange at the end of reaction makes the visual detection for the results of LAMP reaction cost effective and simple without the need of specialized equipment. In addition, a new set of primer was designed based on the identification of major capsid protein (MCP) gene for the specific detection of ISKNV. This new assay is suitable for use in the field and resource limited laboratories as a simple and inexpensive diagnostic tool.

\section{Materials and Methods}

Preparation of ISKNV template DNA

Total genomic DNA from ISKNV infected common platy was extracted using Genomic DNA Mini Kit (Animal Tissues) (Yeastern Biotech) according to the manufacturer's instruction. Full length of ISKNV MCP gene sequence was amplified using Fu et al. (2010) PCR method with minor modifications. The primer set of MCP-F and MCP-R were expected to produce 1,362 bp PCR product. The amplification was performed in $25 \mu \mathrm{L}$ reaction mixture consisted of $2 \mu \mathrm{L}$ of template DNA, $5 \mu \mathrm{L}$ of $5 \times$ green GoTaq flexi buffer (Promega), $2 \mu \mathrm{L}$ of $25 \mathrm{~mm}$ magnesium chloride (Promega), $0.5 \mu \mathrm{L}$ of $10 \mathrm{~mm}$ dNTPs (Promega), $0.25 \mu \mathrm{L}$ of $5 \mathrm{U} / \mu \mathrm{L}$ Taq polymerase (Promega), $2.5 \mu \mathrm{L}$ of $10 \mu \mathrm{m}$ each MCP-F and MCP-R primers (Table 1), and $10.25 \mu \mathrm{L}$ of sterile distilled water. The reaction mixture was incubated in DNA Engine peltier thermal cycler (Bio-Rad) at $94^{\circ} \mathrm{C}$ for $3 \mathrm{~min}$ and then 30 cycles at $94^{\circ} \mathrm{C}$ for $30 \mathrm{~s}, 58^{\circ} \mathrm{C}$ for 45 $\mathrm{s}$ and $72^{\circ} \mathrm{C}$ for $90 \mathrm{~s}$ plus a final $10 \mathrm{~min}$ elongation at $72^{\circ} \mathrm{C}$. The amplified product was analyzed in $2 \%$ agarose gel containing ethidium bromide $(\mathrm{EtBr})$ and visualized using Bio Imaging System (Syngene). The PCR product was then purified using QIAquick PCR purification kit (Qiagen). The purified DNA concentration was quantified using Biophotometer 6131 (Eppendorf) and used as ISKNV template DNA in subsequent experiments.

Table 1. Primers used in this study

\begin{tabular}{llc}
\hline \multicolumn{1}{c}{ Primer name } & \multicolumn{1}{c}{ Oligonucleotide sequence (5'-3') } & Primer reference \\
\hline MCP-F & ATGTCTGCAATCTCAGGT & Fu et al, 2010 \\
MCP $\mathrm{R}$ & TTACAGGATAGGGAAGCCTG & \\
B3 & TGCGACAATCTGATGCACAA & \\
FIP & GAAGAGGGGAATGGGCAAAT & Current study \\
BIP & GTCAAGGAACTCGCTGGTGAGGTTTTGAGGAGGTGTCGGTGTCAT & \\
MCP515f & GGCAGCAAACAGTCTGGCTACATTTTAGTCTGGCCGTTGGTGAT & \\
MCP515r & GTTTGATGCGATGGAGACCC & Go et al., 2006 \\
C1073 & ATGCCAATCATCTTGTTGTAGCC & \\
C1074 & AATGCCGTGACCTACTTTGC & Rimmer et al., 2012 \\
\hline
\end{tabular}


Design of primers for LAMP assay

Based on the highly conserved MCP gene sequence of the ISKNV (Subramaniam et al., 2014: accession No. JX649074), a set of two outer (F3 and B3) and inner primers (FIP and BIP) were designed using the Primer Explorer V4 software available at http://primerexplorer.jp/elamp4.0.0/index.html. The primer sequences for the LAMP reaction were chosen based on their melting temperatures $\left(T_{m}\right)$ range as suggested by Notomi et al. (2000). The forward inner primer (FIP) consisted of complimentary sequence of F1, a TTTT linker and F2. Meanwhile, backward inner primer (BIP) consisted of complimentary sequence of B1, a TTTT linker and B2. TheF3 and B3 primers were designed to facilitate the strand displacement during the early stage of DNA amplification (Notomi et al., 2000).

\section{Determination of reaction conditions for LAMP assay}

LAMP reactions were conducted as described by Notomi et al. (2000) with minor modification. Briefly, LAMP was carried out in $25 \mu \mathrm{L}$ reaction mixture consisted of $0.5 \mu \mathrm{L}$ of $10 \mu \mathrm{m}$ each F3 and B3 (Table 1), 2 $\mu \mathrm{L}$ of $20 \mu \mathrm{M}$ each FIP and BIP (Table 1), $3.5 \mu \mathrm{L}$ of 10 mM dNTPs (Promega), $2.5 \mu \mathrm{L}$ of $10 \times$ ThermoPol $^{\circledR}$ reaction buffer $(20 \mathrm{~mm}$ Tris- $\mathrm{HCl}(\mathrm{pH} 8.8), 10 \mathrm{mM} \mathrm{KCl}$, $6.5 \mathrm{mM} \mathrm{MgSO}_{4}, 10 \mathrm{~mm}\left(\mathrm{NH}_{4}\right)_{2} \mathrm{SO}_{4}, 0.1 \%$ Triton X-100) (New England Biolabs), $1 \mu \mathrm{L}$ of $8 \mathrm{U} / \mu \mathrm{L}$ Bst DNA polymerase large fragment (New England Biolabs), 5 $\mu \mathrm{L}$ of $5 \mathrm{~m}$ Betaine (Sigma Aldrich), $8 \mu \mathrm{L}$ of $25 \mathrm{~mm}$ magnesium chloride (Promega) and $2 \mu \mathrm{L}$ of template DNA $(40 \mathrm{ng})$. All isothermal incubation of the reaction mixtures were carried out in WB 22 waterbath (Memmert).

For the determination of optimum reaction temperature, the mixtures were incubated on pre-determined time (60 $\mathrm{min}$ ) at the following temperatures: 50, 55, 60 and $65^{\circ} \mathrm{C}$. Subsequently for optimum reaction time, the mixtures were incubated at pre-determined temperature $\left(65^{\circ} \mathrm{C}\right)$ at different reaction times: $10,20,30,40,50$ and $60 \mathrm{~min}$. The final LAMP product was analyzed in $2 \%$ agarose gel containing $\mathrm{EtBr}$ and visualized using Bio Imaging System (Syngene).

\section{Analytical specificity of LAMP assay}

The specificity of LAMP primers was evaluated using DNA from red sea bream iridovirus (RSIV) KagYT96 (synonymously designated as RSIV-6 by Kurita and Nakajima (2012)), WSSV (MY/JH/1997), Aeromonas hydrophila (UPM/AAHU/2012) and Vibrio parahaemolyticus (UPM/AAHU/2012). The final LAMP product was analyzed in $2 \%$ agarose gel containing $\mathrm{EtBr}$ and visualized using Bio Imaging System (Syngene). Since only a single RSIV isolate was tested and there were a number of other RSIV sequences from genotype 1 and 2 deposited in GenBank, it is important to investigate the existence of primer-template mismatches which may affect the specificity of the current LAMP assay. Hence, selected MCP gene sequences of RSIV isolates which belong to genotype 1 and 2 were aligned with ISKNV using Jalview (version 2.8.1) to identify the possible mismatches with the LAMP primers.

\section{Analytical sensitivity of LAMP assay}

Tenfold serial dilutions of ISKNV template DNA (starting from $200 \mathrm{pg}$ to $2 \mathrm{ag}$ ) was used to determine the detection limit between LAMP assay, conventional PCR and qPCR. All detection assays were repeated twice. The DNA copy number was determined using the DNA copy number calculator which is available at http://cels.uri.edu/gsc/cndna.html.

The conventional PCR was conducted as described by Go et al. (2006) with minor modifications. The MCP515f and MCP515r primers were expected to produce 399 bp PCR product. The amplification was performed in $25 \mu \mathrm{L}$ reaction mixture consisted of $2 \mu \mathrm{L}$ of template DNA, $5 \mu \mathrm{L}$ of $5 \times$ green GoTaq flexi buffer (Promega), $2.5 \mu \mathrm{L}$ of $25 \mathrm{~mm}$ magnesium chloride (Promega), $0.5 \mu \mathrm{L}$ of $10 \mathrm{~mm}$ dNTPs (Promega), $0.25 \mu \mathrm{L}$ of $5 \mathrm{U} / \mu \mathrm{L}$ Taq polymerase (Promega), $2.5 \mu \mathrm{L}$ of $10 \mu \mathrm{M}$ each MCP515f and MCP515r primers (Table 1), and $10.25 \mu \mathrm{L}$ of sterile distilled water. The reaction mixture was incubated in DNA Engine peltier thermal cycler (Bio-Rad) at $94^{\circ} \mathrm{C}$ for $3 \mathrm{~min}$ and then for 30 cycles at $94^{\circ} \mathrm{C}$ for $30 \mathrm{~s}, 55^{\circ} \mathrm{C}$ for $30 \mathrm{~s}$ and $72^{\circ} \mathrm{C}$ for $60 \mathrm{~s}$. The PCR products were analyzed in $2 \%$ agarose gel containing $\mathrm{EtBr}$ and visualized using Bio Imaging System (Syngene).

The qPCR was carried out as described by Rimmer et al. (2012) with minor modifications. The amplification was performed in $25 \mu \mathrm{L}$ reaction mixture consisted of $2 \mu \mathrm{L}$ of template DNA, $0.75 \mu \mathrm{L}$ of $10 \mu \mathrm{M}$ each $\mathrm{C} 1073$ and C1074 primers (Table 1), $12.5 \mu \mathrm{L}$ of $2 \times$ Quantitect SYBR Green Master Mix (Qiagen) and $9 \mu \mathrm{L}$ of sterile distilled water. The reaction was performed using CFX 96 Real Time PCR Detection System (Bio-Rad) at $95^{\circ} \mathrm{C}$ for $15 \mathrm{~min}$ and then for 40 cycles at $95^{\circ} \mathrm{C}$ for $30 \mathrm{~s}, 62^{\circ} \mathrm{C}$ for $30 \mathrm{~s}$ and $72^{\circ} \mathrm{C}$ for $30 \mathrm{~s}$ with fluorescence acquisition at the end of the final annealing step.

\section{Visualization of LAMP product}

The sensitivity of LAMP using acridine orange (1:100 dilution of $10 \mathrm{mg} / \mathrm{mL}$ stock solution) was determined by subjecting the assay to tenfold serial diluted ISKNV template DNA. The serial dilution of the template DNA was prepared as described at section titled "Analytical sensitivity of LAMP assay". A $10 \mu \mathrm{L}$ of diluted acridine orange was added at the end of the reaction and observed for color change by the naked eye. 
Detection of ISKNV in fish tissues by LAMP assay

Total of 30 asymptomatic fish samples (ram cichlid, $\mathrm{n}=15$; swordtail, $\mathrm{n}=15$ ) which were previously tested for the presences of ISKNV by OIE PCR assay (Subramaniam et al., 2014) were used in this study to investigate the feasibility of the LAMP assay. For each individual fish samples, visceral organs (spleen, liver and kidney) were pooled and total genomic DNA was extracted using Genomic DNA Mini Kit (Animal Tissues) (Yeastern Biotech) according to the manufacturer's instruction. A $2 \mu \mathrm{L}$ of extracted DNA then added into LAMP reaction mixture and incubated at $65^{\circ} \mathrm{C}$ for 60 min in WB 22 waterbath (Memmert). After the incubation, $10 \mu \mathrm{L}$ of diluted acridine orange dye was added into the tube to detect the presence of amplified product.

\section{Results}

Determination of reaction conditions for LAMP assay

The LAMP reaction was performed using PCR amplicon as ISKNV template DNA to determine the optimal reaction temperature and time. No amplification was detected at $50^{\circ} \mathrm{C}$ at time range from 10 to $30 \mathrm{~min}$. Weak bands was observed at temperature range from 55 to $60^{\circ} \mathrm{C}$ and at time range from 40 to $50 \mathrm{~min}$. Bright bands were observed at $65^{\circ} \mathrm{C}$ and $60 \mathrm{~min}$; hence, it was regarded as optimum temperature and time for the LAMP assay. The amplified LAMP product appeared as a ladder-like pattern on agarose gel and no amplification was observed in the negative control. The optimum reaction conditions were used in subsequent experiments.

\section{Analytical specificity of the LAMP assay}

The specificity of the LAMP primers was determined by testing the cross-reactivity of the assay among ISKNV, RSIV, WSSV, Aeromonas hydrophila and Vibrio parahaemolyticus. Of these pathogens, positive result was obtained only for ISKNV. No amplification was detected for the other samples including the RSIV, which was from the same genus as ISKNV (Fig. 1). Therefore, the LAMP primers were specific for ISKNV. A total of six RSIV MCP gene sequences were obtained from GenBank. Of these, RSIV-Ehime1 (Kurita and Nakajima, 2012: accession No. AB080362), RSIV-2HSB (Kurita and Nakajima, 2012: accession No. AB666318) and RSIV-TGA12 (Kurita and Nakajima, 2012: accession No. AB666319) belong to RSIV genotype 1, whereas RSIV-6 (Kurita and Nakajima, 2012: accession No. AB666333), RSIV-9371 (Kurita and

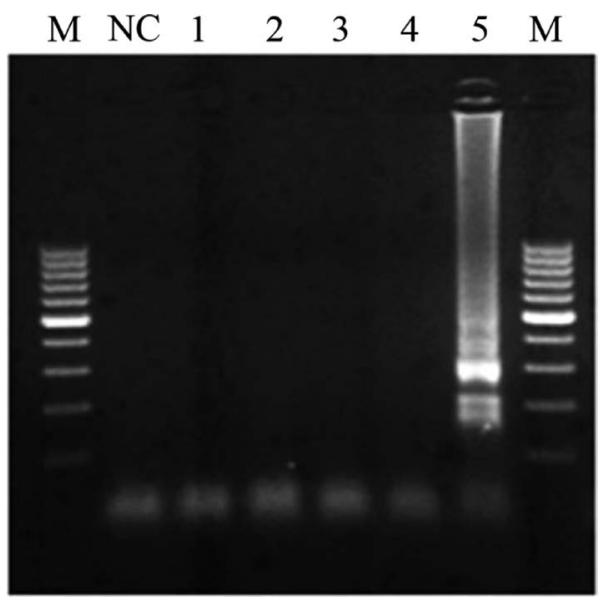

Fig. 1. Specificity of the LAMP primers. (Lane 1) Red sea bream iridovirus (RSIV KagYT96), (Lane 2) white spot syndrome virus (WSSV), (Lane 3) Aeromonas hydrophila, (Lane 4) Vibrio parahaemolyticus and (Lane 5) infectious spleen and kidney necrosis virus (ISKNV). NC: negative control. M: 100 bp DNA ladder (Fermentas).

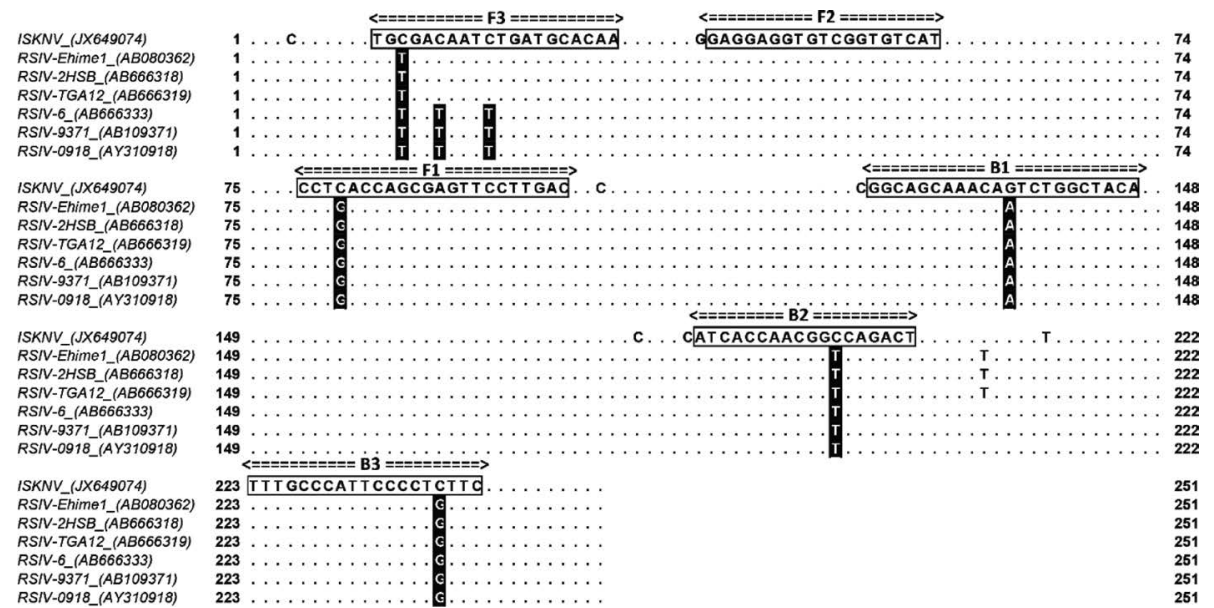

Fig. 2. Nucleotide mismatches in the MCP gene sequences between ISKNV and RSIV. Dot indicates identical nucleotide among the virus isolates. Boxes indicate the positions of the six LAMP primers (F3, F2, F1, B3, B2 and B1) regions designed based on the ISKNV MCP gene sequence (accession No. JX649074). The RSIV MCP gene sequences have mismatches at the LAMP primer sites. RSIV-Ehime 1, RSIV-2HSB and RSIV-TGA12 belong to RSIV genotype 1, whereas RSIV-6, RSIV-9371 and RSIV-0918 belong to RSIV genotype 2. Figure in parentheses shows accession number in the GenBank. 
Nakajima, 2012: accession No. AB109371) and RSIV0918 (Kurita and Nakajima, 2012: accession No. AY310918) belong to RSIV genotype 2. The RSIV MCP gene sequences that have mismatches with the LAMP primers were identified in an alignment based on the ISKNV MCP gene sequence (Subramaniam et al., 2014: accession No JX649074) (Fig. 2). Primer F2 completely matches all the aligned RSIV sequences. Primer F1, B1, B2 and B3 had one nucleotide mismatch in all the RSIV sequences from genotype 1 and 2 . Primer F3 had one nucleotide mismatch in the RSIV sequences from genotype 1 and had three nucleotide mismatches in the RSIV sequences from genotype 2 .

\section{Analytical sensitivity of LAMP assay}

The sensitivity of the LAMP was compared with the established PCR and qPCR assays for diagnosis of ISKNV infection. According to the result, LAMP was able to detect the template at $10^{-5}$ dilution (equivalent to 20 fg DNA or $1.4 \times 10^{4}$ DNA copies). Conventional PCR and qPCR were able to detect the template at $10^{-6}$ dilution (equivalent to $2 \mathrm{fg}$ DNA or $1.4 \times 10^{3}$ DNA copies) and $10^{-9}$ dilution (equivalent to 2 ag DNA or $1.4 \times$ $10^{\circ}$ DNA copies) respectively (Table 2 ).

\section{Visualization of LAMP product}

Visual inspection of amplified LAMP product was performed by adding diluted acridine orange which is more economical compared to EtBr, SYBR Green 1, calcein and propidium iodide. After the addition of $10 \mu \mathrm{L}$ dye into LAMP reaction tube, the solution turned yellow indicating positive reaction and remain orange on nega- tive reaction. Current $\mathrm{LAMP}$ is able to detect the template DNA at $10^{-5}$ dilution (Fig. 3) and the results of the assay can be visualized by naked eye without the need of any special lighting or equipment.

\section{Detection of ISKNV in fish tissues by LAMP assay}

A total of 30 samples comprises of two different fish species (ram cichlid and swordtail) were subjected to the LAMP assay. Of these, 14 were identified positive for ISKNV and the result of the LAMP assay is the same as that of OIE PCR assay (Table 3).

\section{Discussion}

In the current study, LAMP method targeting MCP gene was successfully developed for the detection of ISKNV. The MCP gene sequence was selected as target for the LAMP assay because it is highly conserved among members of the family Iridoviridae and can be used to distinguish closely related isolates of iridovirus (Tidona et al., 1998).

The optimal reaction condition for the LAMP assay is $65^{\circ} \mathrm{C}$ for $60 \mathrm{~min}$ and it was determined based on the clarity of the DNA bands in agarose gel. The amplified DNA appears as a smear and ladder-like pattern on gel

Table 3. The comparison of the ISKNV detection results between the OIE PCR assay and LAMP assay

\begin{tabular}{ccc}
\hline Fish species & $\begin{array}{c}\text { OIE PCR assay } \\
\text { (Positive/Negative) }\end{array}$ & $\begin{array}{c}\text { LAMP assay } \\
\text { (Positive/Negative) }\end{array}$ \\
\hline Ram cichlid & $12 / 3$ & $12 / 3$ \\
Swordtail & $2 / 13$ & $2 / 13$ \\
\hline
\end{tabular}

Table 2. Comparison of the detection limits between $\mathrm{PPCR}, \mathrm{PCR}$ and LAMP using 10-fold serial dilution of ISKNV template DNA

\begin{tabular}{cccccc}
\hline Dilution & $\begin{array}{c}\text { DNA copy } \\
\text { number }\end{array}$ & $\begin{array}{c}\text { DNA } \\
\text { concentration }\end{array}$ & $\begin{array}{c}\text { qPCR } \\
\text { (mean } \mathrm{c}_{\mathrm{t}} \text { value) }\end{array}$ & $\begin{array}{c}\text { Conventional } \\
\text { PCR }\end{array}$ & LAMP \\
\hline $10^{-1}$ & $1.4 \times 10^{8}$ & $200 \mathrm{pg}$ & $+(11.00)$ & + & + \\
$10^{-2}$ & $1.4 \times 10^{7}$ & $20 \mathrm{pg}$ & $+(14.15)$ & + & + \\
$10^{-3}$ & $1.4 \times 10^{6}$ & $2 \mathrm{pg}$ & $+(17.34)$ & + & + \\
$10^{-4}$ & $1.4 \times 10^{5}$ & $200 \mathrm{fg}$ & $+(20.56)$ & + & + \\
$10^{-5}$ & $1.4 \times 10^{4}$ & $20 \mathrm{fg}$ & $+(23.89)$ & + & + \\
$10^{-6}$ & $1.4 \times 10^{3}$ & $2 \mathrm{fg}$ & $+(27.74)$ & + & - \\
$10^{-7}$ & $1.4 \times 10^{2}$ & $200 \mathrm{ag}$ & $+(30.72)$ & - & - \\
$10^{-8}$ & $1.4 \times 10^{1}$ & $20 \mathrm{ag}$ & $+(34.70)$ & - & - \\
$10^{-9}$ & $1.4 \times 10^{0}$ & $2 \mathrm{ag}$ & $+(35.77)$ & - & - \\
$10^{-10}$ & 0 & 0 & $-\left(\mathrm{no} \mathrm{c}_{t}\right)$ & - & - \\
\hline
\end{tabular}

'+' successful amplification, '-' negative reaction.

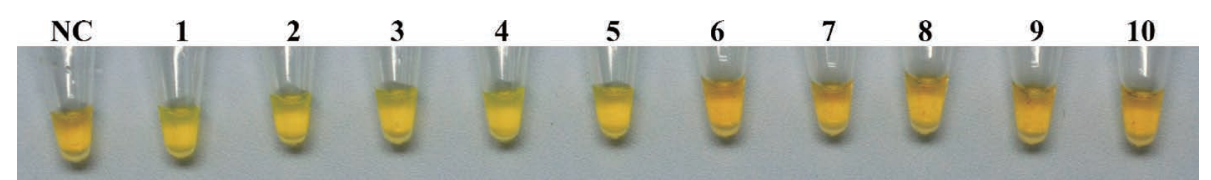

Fig. 3. The sensitivity of LAMP assay using acridine orange. The solution turned yellow (1 to 5 ) indicating positive reaction and appeared orange (6 to 10) on negative reaction. The numbers $1-10$ show the dilutions of template DNA, $10^{-1}$ to $10^{-10}$. NC: negative control. 
due to the production of various lengths of stem loop structures with repeated target sequence (Kuboki et al., 2003; Savan et al., 2005). In contrast to the present results, other reports have shown the ability of the Bst polymerase to amplify DNA templates at temperatures lower than $65^{\circ} \mathrm{C}$. Li et al. (2010) have developed LAMP method for the detection of lymphocystis disease virus (LCDV) and according to them; the optimal reaction temperature was $63^{\circ} \mathrm{C}$. In another study, Woźniakowski et al. (2012) reported $61^{\circ} \mathrm{C}$ as optimal temperature for the detection of goose circovirus (GoCV). Hence, Bst polymerase is able to amplify DNA templates with high efficiency at temperature range of $61-65^{\circ} \mathrm{C}$ within $60 \mathrm{~min}$.

Nagamine et al. (2002) have demonstrated that the additions of loop primers (loop forward [LF] and loop backward [LB]) were able to accelerate the LAMP reaction, however, in current study the presence of these primers resulted in false-positive (data not shown). Similar observation was reported by Pillai et al. (2006) and according to them the non-specific amplification is due to self-priming of the loop primers. Therefore, loop primers were not included in the current study to ensure reliability of the LAMP assay.

Accurate identification of the pathogens using highly specific diagnostic tool is important to control the spread of infectious diseases. One of the advantages of present LAMP assay was its specificity towards ISKNV. The LAMP reaction is highly specific because in template DNA, the primers recognize six regions at the initial stage of reaction and four regions at the later stage of reaction (Notomi et al., 2000). Previous LAMP assay for ISKNV was developed based on DNA polymerase (DPOL) gene by Ding et al. (2010) and it was not tested for cross reactivity against RSIV which belongs to the same genus as ISKNV. Similarly the RSIV LAMP assay developed by Caipang et al. (2004) was not tested for cross reactivity against ISKNV. Thus, the current LAMP assay can be used as a diagnostic tool to detect the presence of ISKNV and to distinguish from RSIV. Multiple sequence alignment of MCP gene sequences of RSIV isolates including RSIV-6 used in this study showed the existence of sequence variations at LAMP primer binding site. Hence, it is suggested that the mismatches between the LAMP primers and targeted MCP gene sequence prevent the current LAMP assay from amplifying the tested RSIV DNA. This makes the present LAMP assay highly specific for ISKNV. In support of this, Li et al. (2009) reported that the false-negative results was obtained in 5 of 21 different Newcastle disease virus (NDV) strains due to the mismatches between the target gene and LAMP primers. In addition, Salinas and Little (2012) also have predicted that there will be no amplicons on Staphylococcus aureus genome because of mismatches between LAMP primers and template.
Based on the result, qPCR showed highest sensitivity and able to detect the template DNA at $10^{-9}$ dilution and in PCR assay, a weak band was observed at $10^{-6}$ dilution. Although the sensitivity of LAMP is slightly lower than PCR, yet it is highly specific for ISKNV. In addition, the devised assay only requires simple equipment such as heating block or water bath compared to PCR assay which requires expensive equipment such as thermal cycler and gel documentation. Our current finding on the sensitivity of LAMP assay is similar to the reports by Kuboki et al. (2003), Müller et al. (2010) and Khan et al. (2012). According to Kuboki et al. (2003), a PCR was more sensitive compared to LAMP due to minimum contamination of blood components in the template DNA. In the present study, purified PCR product was used as ISKNV template DNA and it contains less Taq DNA polymerase inhibitors which might have enhanced the efficiency of the PCR reaction. In addition, Zhang et al. (2009) suggested that the differences in sensitivity may be related to LAMP primers and reaction conditions. Hence, the improvement on the sensitivity of the LAMP assay requires further studies.

Amplified LAMP product can be detected by examining the presence of white precipitates at the end of the reaction. According to Mori et al. (2001), the white precipitation of magnesium pyrophosphate was formed as a combination of magnesium ion from LAMP reaction buffer and pyrophosphate ion which was released from deoxyribonucleotide triphosphate (dNTP) during DNA polymerization. Besides that, DNA intercalating dyes or metal indicators can be added to facilitate the detection of the amplified product.

Sung et al. (2010) have used EtBr to visualize the LAMP product. According to them, the positive and negative reaction yield pink and orange color respectively. The SYBR Green 1 (SG) on the other hand turns green on positive reaction and remains orange in negative reaction (Soliman and El-Matbouli, 2006). Propidium iodide was utilized by Hill et al. (2008) and pink coloration was formed in the positive reaction while deep redorange formed in negative reaction. Hydroxynaphthol blue is a metal indicator which was used by Wastling et al. (2010) and according to them, sky blue coloration indicates positive reaction and violet coloration indicates otherwise.

Previously described LAMP assay for ISKNV (Ding et al., 2010) utilizes lateral flow dipstick (LFD) to detect the amplified product. At the end of the amplification step, the LAMP product has to be incubated with hybridization probe for $5 \mathrm{~min}$ at $60-65^{\circ} \mathrm{C}$. Then, followed by dipping the LFD strip into a mixture (hybridized LAMP product + reaction buffer) for 5 min to obtain the final result. Even though this technique is useful for field detection, the additional time-consuming post reaction procedures increase the risk of contamination and cost. Thus, in current study acridine orange was used to 
detect the presence of LAMP product and there is no previous report describing the successful use of this dye to identify the amplified product. The acridine orange turns the LAMP product into yellow, indicating positive reaction and remains orange on negative reaction. The changes in the color can be visualized easily without the need of special lighting or expensive equipment. Acridine orange is an inexpensive dye and can be stored at room temperature. Usage of acridine orange makes the detection of amplified LAMP product simple and applicable in the field.

In conclusion, present LAMP technique is an inexpensive and simple diagnostic tool available for the detection of ISKNV under laboratory conditions and also for use in the field. This new LAMP method is specific for ISKNV and can be a useful tool to monitor the virus as a preventive measure to ensure a healthy development of the aquaculture industry.

\section{Acknowledgements}

We thank Dr. Norihisa Oseko and Dr. Takafumi Ito (OIE reference laboratory for RSIVD, Japan) for providing RSIV KagYT96 genomic DNA and Dr. Tan Sheau Wei (Laboratory of Vaccines and Immunotherapeutic, Institute of Bioscience, Universiti Putra Malaysia) for her excellent assistance in carrying out the qPCR assay. The first author acknowledges the scholarship (MyPhD) provided by Ministry of Higher Education Malaysia for his PhD study. The authors acknowledge Research University Grants Scheme (RUGS), Universiti Putra Malaysia, project number 0505101114RU.

\section{References}

Ambrosia, R. E. and D. T. De Wall (1990): Diagnosis of parasitic disease. Rev. Sci. Tech. Off. Int. Epizoot., 9, 759778.

Armstrong, R. D. and H. W. Ferguson (1989): Systemic viral disease of the chromide cichlid Etroplus maculates. J. Aquat. Anim. Health, 7, 155-157.

Biswas, G. and M. Sakai (2014): Loop-mediated isothermal amplification (LAMP) assays for detection and identification of aquaculture pathogens: current state and perspectives. Appl. Microbiol. Biot., 98, 2881-2895.

Caipang, C. M. A., I. Haraguchi, T. Ohira, I. Hirono and T. Aoki (2004): Rapid detection of a fish iridovirus using loop-mediated isothermal amplification (LAMP). J. Virol. Methods, 121, 155-161.

Ding, W. C., J. Chen, Y. H. Shi, X. J. Lu and M. Y. Li (2010): Rapid and sensitive detection of infectious spleen and kidney necrosis virus by loop-mediated isothermal amplification combined with a lateral flow dipstick. Arch. Virol., 155, 385-389.

Fu, X., N. Li, L. Liu, Q. Lin, F. Wang, Y. Lai, H. Jiang, H. Pan, C. Shi and S. Wu (2010): Genotype and host range analysis of infectious spleen and kidney necrosis virus (ISKNV). Virus Genes, 42, 97-109.

Go, J., M. Lancaster, K. Deece, O. Dhungyel and R. Whittington (2006): The molecular epidemiology of iridovirus in Murray cod (Maccullochella peelii peelii) and dwarf gourami (Colisa lalia) from distant biogeographical regions suggests a link between trade in ornamental fish and emerging iridoviral diseases. Mol. Cell. Probe., 20, 212-222.

Goto, M., E. Honda, A. Ogura, A. Nomoto and K. I. Hanaki (2009): Colorimetric detection of loop mediated isothermal amplification reaction by using hydroxy naphthol blue. Biotechniques, 46, 167-172.

Hill, J., S. Beriwal, I. Chandra, V. K. Paul, A. Kapil, T. Singh, R. M. Wadowsky, V. Singh, A. Goyal, T. Jahnukainen, J. R. Johnson, P. I. Tarr and A. Vats (2008): Loop-mediated isothermal amplification assay for rapid detection of common strains of Escherichia coli. J. Clin. Microbiol., 46, 2800-2804.

Khan, G. M., K. R. H. Bhaskar, A. Salam, T. Akther, G. Pluschke and D. Mondal (2012): Diagnostic accuracy of loop-mediated isothermal amplification (LAMP) for detection of Leishmania DNA in buffy coat from visceral leishmaniasis patients. Parasites \& Vectors, 5, 280.

Kuboki, N., D. J. Grab, N. Inoue, H. Suzuki, T. Sakurai, C. Sugimoto, F. Di Cello and I. Igarashi (2003): Loop-mediated isothermal amplification for detection of African trypanosomes. J. Clin. Microbiol., 41, 5517-5524.

Kurita, J. and K. Nakajima (2012): Megalocytiviruses. Viruses, 4, 521-538.

Li, Q., C. Xue, J. Qin, Q. Zhou, F. Chen, Y. Bi and Y. Cao (2009): An improved reverse transcription loop-mediated isothermal amplification assay for sensitive and specific detection of Newcastle disease virus. Arch. Virol., 154, 1433-1440.

Li, Q., Z. Yue, H. Liu, C. Liang, X. Zheng, Y. Zhao, X. Chen, X. Xiao and C. Chen (2010): Development and evaluation of a loop-mediated isothermal amplification assay for rapid detection of lymphocystis disease virus. J. Virol. Methods, 163, 378-384.

Meyer, F. P. (1991): Aquaculture disease and health management. J. Anim. Sci., 69, 4201-4208.

Müller, H., N. Aysul, Z. Liu, D. A. Salih, T. Karagenc, D. Beyer, B. Kullmann, J. S. Ahmed and U. Seitzer (2010): Development of a loop-mediated isothermal amplification (LAMP) assay for rapid diagnosis of Babesia canis infections. Transbound. Emerg. Dis., 57, 63-65.

Nagamine, K., T. Hase and T. Notomi (2002): Accelerated reaction by loop-mediated isothermal amplification using loop primers. Mol. Cell. Probes, 16, 223-239.

Notomi, T., H. Okayama, H. Masubuchi, T. Yonekawa, K. Watanabe, N. Amino and T. Hase (2000): Loop-mediated isothermal amplification of DNA. Nucleic Acids Res., 28, 63.

Mori, Y., K. Nagamine, N. Tomita and T. Notomi (2001): Detection of loop-mediated isothermal amplification reaction by turbidity derived from magnesium pyrophosphate formation. Biochem. Bioph. Res. Co., 289, 150-154.

Paperna, I., V. Margarita and A. P. A. de Matos (2001): Iridovirus infections in farm-reared tropical ornamental fish. Dis. Aquat. Org., 48, 17-25.

Pillai, D., J. R. Bonami and J. S. Widada (2006): Rapid detection of Macrobrachium rosenbergii nodavirus (MrNV) and extra small virus (XSV), the pathogenic agents of white tail disease of Macrobrachium rosenbergii (De Man), by loopmediated isothermal amplification. J. Fish Dis., 29, 275-283.

Rimmer, A. E., J. A. Becker, A. Tweedie and R. J. Whittington (2012): Development of a quantitative polymerase chain reaction (qPCR) assay for the detection of dwarf gourami iridovirus (DGIV) and other megalocytiviruses and comparison with the Office International des Epizooties (OIE) 
reference PCR protocol. Aquaculture, 358-359, 155163.

Salinas, N. R. and D. P. Little (2012): Electric LAMP: Virtual Loop-Mediated Isothermal Amplification. ISRN Bioinformatics, 2012, 696758.

Savan, R., T. Kono, T. Itami and M. Sakai (2005): Loop-mediated isothermal amplification: an emerging technology for detection of fish and shellfish pathogens. J. Fish Dis., 28, $573-581$.

Soliman, H. and M. El-Matbouli (2006): Reverse transcription loop-mediated isothermal amplification (RT-LAMP) for rapid detection of viral hemorrhagic septicaemia virus (VHS). Vet. Microbiol., 114, 205-213.

Song, J. Y., S. I. Kitamura, S. J. Jung, T. Miyadai, S. Tanaka, Y. Fukuda, S. R. Kim and M. J. Oh (2008): Genetic variation and geographic distribution of megalocytiviruses. J. Microbiol., 46, 29-33.

Subramaniam, K., M. Shariff, A. R. Omar and M. Hair-Bejo (2012): Megalocytivirus infection in fish. Rev. Aquaculture, 4, 221-233.

Subramaniam, K., M. Shariff, A. R. Omar, M. Hair-Bejo and B. L. Ong (2014): Detection and molecular characterization of infectious spleen and kidney necrosis virus from major ornamental fish breeding states in Peninsular Malaysia. J. Fish Dis., 37, 609-618.

Sudthongkong, C., M. Miyata and T. Miyazaki (2002): Iridovirus disease in two ornamental tropical freshwater fishes: African lampeye and dwarf gourami. Dis. Aquat. Org., 48, 163-173.

Sung, C. H., S. C. Chi, K. C. Huang and J. K. Lu (2010): Rapid detection of grouper iridovirus by loop-mediated isothermal amplification. J. Mar. Sci. Technol., 18, 568-573.
Tidona, C. A., P. Schnitzler, R. Kehm and G. Darai (1998): Is the major capsid protein of iridoviruses a suitable target for the study of viral evolution? Virus Genes, 16, 59-66.

Tomita, N., Y. Mori, H. Kanda and T. Notomi (2008): Loop-mediated isothermal amplification (LAMP) of gene sequences and simple visual detection of products. Nat. Protoc., 3, 877-882.

Tomlinson, J. A., I. Barker and N. Boonham (2007): Faster, simpler, more-specific methods for improved molecular detection of Phytophthora ramorum in the field. Appl. Environ. Microbiol., 73, 4040-4047.

Wastling, S. L., K. Picozzi, A. S. L. Kakembo and S. C. Welburn (2010): LAMP for human African trypanosomiasis: A comparative study of detection formats. Plos Neglect. Trop. D., 4, e865.

Wang, Y. Q., L. Lu, S. P. Weng, J. N. Huang, S. M. Chan and J.G. He (2007): Molecular epidemiology and phylogenetic analysis of a marine fish infectious spleen and kidney necrosis virus-like (ISKNV-like) virus. Arch. Virol., 152, 763-773.

Whittington, R. J. and R. Chong (2007): Global trade in ornamental fish from an Australian perspective: The case for revised import risk analysis and management strategies. Prev. Vet. Med., 81, 92-116.

Woźniakowski, G., W. Kozdruń and E. Samorek-Salamonowicz (2012): Loop-mediated isothermal amplification for the detection of goose circovirus. Virol. J., 9, 110.

Zhang, Q., C. Shi, J. Huang, K. Jia, X. Chen and H. Liu (2009): Rapid diagnosis of turbot reddish body iridovirus in turbot using the loop-mediated isothermal amplification method. J. Virol. Methods, 158, 18-23. 